\title{
Exploration and Practice of the Teaching of Collecting Music in Normal Colleges Based on the Protection of Intangible Cultural Heritage*
}

\author{
Qunying Wang \\ Academy of Music \\ Shaoguan University \\ Shaoguan, China 512005
}

\begin{abstract}
The collecting music is an teaching platform of art practice based on theory and practice. The music major in local colleges and universities should improve teaching quality and enhance the "service" for the local community and culture. In the teaching arrangements and implementation of collecting music, the teachers can dig, organize, protect and inherit the local ethnic intangible cultural heritage of folk music. And the teachers could update teaching philosophy, improve teaching methods, broaden the perspective of art education reform and open up a new path of art practice in higher normal colleges. They could further inherit and carry forward the folk music art of ethnic groups. The course could service for music education, the construction of humanities discipline, and the local protection of intangible cultural heritage of folk music arts.
\end{abstract}

Keywords-musicology in normal colleges; intangible cultural heritage; music collection

\section{INTRODUCTION}

UNESCO formally adopted the "Convention for the Safeguarding of the Intangible Cultural Heritage" in Paris in October 2003. The concept of intangible cultural heritage began to enter the eyes of the people. Intangible cultural heritage refers to the practices, performances, manifestations, knowledge, skills, related tools, objects, arts, crafts and cultural sites believed by various groups and personnel (Xiang Yunju, 2006). Intangible cultural heritage is comprehensive reflection of expressive force, creativity, contagious power, production and living customs and folk customs. It carries distinctive national memories and profound cultural genes (Zhang Xinxin, Wen Zhen, 2015). The Chinese government has always attached great importance to the protection and research of cultural heritage. Taking the cultural heritage of music and dance as an example, China started to carry out "Integration of Chinese Folk Song Music", "Chinese traditional opera music integration", "Integration of folk dance of Chinese nationalities", "Integration of music of popular narratives in

Fund Project: It is the phased achievements of "Exploration and Practice of the Teaching of Collecting music in Normal Colleges Based on the Protection of intangible cultural heritage", which is supported by the 17th Research Project of Education and Teaching Reform in Shaoguan University (SYJY20161718)
China" and "Integration of Chinese Instrumental Music" in the 1950s. The large-scale nationwide study and compilation of "Chinese Opera Records" (integration of Chinese opera) conducted in the 1980s are good examples. The project of safeguarding intangible cultural heritage, which was carried out in the country in recent ten years, has essentially inherited the arrangement and presentation of the intangible cultural heritage of music. Also, it has deepened the compilation of music integration. And it brings the study of music up to the culture value.

The history of "music collection" is very long. "Wordocean dictionary" refers to the folk songs in the ancient times. And it is called the collection of folk songs. According to "Yiwenzhi from Hanshu", it summarizes the functions that "the person who is the king (through collected poems) observes the customs, knows the gains and losses of the administration, and examines whether or not his actions fit the law." The concept of music collection is confined to the collection of folk songs. It has been extended to the living, material, excavation, sorting, protection and research of folk arts and cultural field trips.

"Music collection" is professional practice course. And it is commonly held in the art education of higher normal colleges. It has a great influence on the accumulation of students' professional knowledge, the development of students' horizons, the formation of professional education thoughts, the enhancement of the practical ability of the theory and practice. It plays an important irreplaceable function and role. In 2015, the Research Center of Local Music and Dance (we could use the Center) was set up by Shaoguan University. Since it was established, the center has signed strategic cooperation agreements with the Propaganda Department of the Municipal Party Committee. It would undertake the protection project of intangible cultural heritage and collaborate in education. And it has begun to explore the combination of music collection of students and protection of local intangible cultural heritage. This paper would take the teaching reform of music collection and local intangible cultural heritage protection as the example. This article explores the new vision and new ways to improve the teaching quality of music collection. 


\section{COMBINING Music COLLECTION WITH INTANGIBLE Cultural Heritage Protection, AND It CAN ACHIEVE MULTI-WIN EFFECT}

The major of musicology in local colleges and universities, especially normal majors, faces two major challenges. First, it is the guarantee of teaching quality after the expansion of enrollment. Second, the applied undergraduate education should strengthen local service and contribution. The colleges must have the teaching reform that combines music collection with intangible cultural heritage protection.

First of all, this combination would increase college students' recognition of local culture and inherit the essence of local music and traditional culture. Through organizing music collection, students are influenced by the excellent culture of local arts. And they would love local music. Also, they are willing to inherit the local music. In this way, students would learn about rich and touching regional folk music outside the classroom. And they are deeply touched by these local cultures. As students, they want to know what they can do to protect these folk gems. And we could know that in the class and daily education, the students can't directly have such awareness and intuitive feeling of the native folk culture. During the period of collecting the music, students can also learn to sing from local masses and folk entertainers. They can bring back some folk instruments. It would stimulate the initiative of learning and research. The art collection would give students fresh stimulation of professional study, enhance the sense of mission, responsibility and discipline of students and strengthen the cohesion of the class in meticulous and realistic social investigation. It can cultivate sentiments, broaden their horizons and artistic inspiration, and enhance the ability to feel the beauty, appreciate the beauty, show the beauty and create the beauty. Also, it would improve the concept of solidarity and collectivism. In the activities of collecting folk songs, the Center encourages students to participate in routine management of field trips. It would exercise comprehensive capabilities such as management, organization, communication, safety awareness and innovation. The students would walk out of the classroom and enter into the community. As future music teachers, the students should bear the social responsibility, education responsibility and cultural heritage responsibility.

Secondly, this combination is conducive to promoting the development of local music and cultural construction. Through organizing large-scale systematic and comprehensive study of local music fields and collecting folk songs, the paper summarizes the studies on local music, puts forward suggestions for the improvement of local music in terms of optimizing and developing local music, promoting the extraction of local musical elements in northern Guangdong province, and improving the quality of music creation in the local stage. Then, it would promote cultural development and construction of local music.

Third, this combination effectively promotes the digitization and protection of local music resources. It lacks culture books and audio materials on the music in northern
Guangdong province. And there are few of music collection. And these collections are dispersed. The center and music collection groups have proposed to construct digitalized database of local music in northern Guangdong and build an important base for local cultural innovation. The local music and cultural resources in northern Guangdong can be fully exploited and utilized. It would reflect the new cultural spirit, promote local traditional ethnic cultures and improve the digitization of local music resources and the protection.

Fourthly, the excavation and protection of local music culture in northern Guangdong conforms to the need of the times. It aims at actively building the pluralistic music culture under the background of globalization. While recording and studying the local music in northern Guangdong, it pays special attention to the protection from the source, such as the recording of endangered music, the protection and cultivation of inheritors, the entry of local music into the classroom, especially the combination of music classroom teaching in colleges and universities and folk inheritance. It should take the protection from the original ecological characteristics of music. And it may try to have the innovation and development. It would find a way to effectively promote the healthy development of local music in northern Guangdong.

Fifthly, the government and the professional team of colleges and universities should carry out large-scale project of collecting music with the cultural resources. Through collaborative innovation and optimization of resource allocation, we should explore a new approach to cultivate local music and distinctive musical forms in northern Guangdong. The center would organize college teachers to classify local music culture and arts in northern Guangdong. According to different areas, nationalities and categories, the teachers should make the music collection. They threedimensional music database in Guangdong should be contextualized, graphic, audio and video and digital. The systematic series of work would be in place. Through gathering the strengths of all parties, the protection for folk music in northern Guangdong would get fruitful results. For the protection for folk music arts heritage in three districts and eight counties, the center should serve the construction of local culture, actively dig, rescue and fix endangered intangible cultural heritage in northern Guangdong. The center should cooperate with other departments such as the Bureau of Arts and Culture, the Arts and Culture Department and other departments. They could employ external professors, visiting professors and consultants, integrate resources, unite forces and work together for innovation. The center will actively tap, collect, organize and present local music and cultural resources. It would improve the process of protection and development of intangible cultural heritage. And then, it could serve and promote the healthy and rapid development of local culture.

Sixth, this combination can deepen and enhance the features of local music, promote the creation of the city's music art brand and create conditions for the local cultural construction. The center conducts activities such as collecting folk songs, sorting and excavating folk music with local characteristics. And then, the center conducts various 
forms of lecture to create folk music associations and new media. It would disseminate local folk music. Also, the center should organically integrate the protection, innovation and development. Combined with the continuation of the vitality of folk music art, it would explore a new path for the construction of "cultural Shaoguan".

The combination is conformed to the scientific concept of development and the law of higher education. It would practice collaborative training of personnel. And the development orientation of colleges and universities should be consistent with the objectives of personnel training. It can further enhance the innovation ability, improve personnel training, promote the construction of music connotation, and highlight the characteristics of running local applied university.

\section{The Status QuO OF Music COLLECTION COURSES AND THE PROTECTION FOR INTANGIBLE CULTURAL HERITAGE AND EXISTING PROBLEMS}

The proportion of the traditional music syllabus in the setting of artistic practice is still too small. The colleges and universities should increase the proportion of artistic practice correspondingly. Now, with the needs of talent market for music professionals, the colleges and universities should pay more attention to the cultivation of compound talents. That is to say, the market needs multi-capable talents. Therefore, the colleges and universities should have the adjustment according to the demands of the talent market. In the teaching process, it should make the allocation based on the reasonable proportion of theoretical class and art practice activities. Through effective training mode, students can be trained and improved in many aspects such as theoretical knowledge, artistic practice and organizational skills. The students would get the improvement in learning process.

Traditional music teaching has few opportunities to cooperate with local music resources. It is not down to earth. The colleges and universities could carry out activities such as collecting, sorting, arranging and excavating folk songs in northern Guangdong with local characteristics. And then, they could conduct various lectures in campus and the classrooms. With the establishment of folk music organizations and the dissemination of new media, it could undertake local folk music. It would be in line with the requirements of creating an educational model with local characteristics for local colleges and universities.

Local music in northern Guangdong is rich in content. It has accumulated profound historical and cultural connotations. Also, it has undertaken ordinary people's praise and pursuit of good life. Each region of northern Guangdong has its own unique form of folk music. Its musical characteristics, styles, spin, melody and singing styles are very different. And it reflects different national characteristics. However, the current local music in northern Guangdong as well as many other folk music in the whole country has become increasingly weak due to the impact of the commercial tide. The ecological environment for music is severe. The geographical distribution becomes increasingly narrow. The number of participants reduced. It lacks the protection and utilization of special funds for folk arts and culture. Many arts and cultures are in critical danger. However, the endangerment does not simply mean the fragility, "passing away" and "death" of local music culture in northern Guangdong. On the contrary, the reasons why local music in northern Guangdong can survive show the stubbornness of their existence. They have maintained their vitality by their own unique strength and path. The protection of them is not a kind of "affirmation" of "immortality". The endangered cultures still have value. Local music in northern Guangdong is a mirror that reflects the culture of northern Guangdong, Hakka folk customs, national memories and the way of thinking of people in northern Guangdong. Therefore, studying and protecting local music in northern Guangdong is not only to protect music art, but also to better protect people's spiritual home in northern Guangdong. Many veteran artists have died. And some of music art have disappeared. People have pity. From now on, we should still strengthen the protection.

On October 11, 2010, the Municipal Party Committee and Municipal Government developed the "Opinions on Implementing the Outline of Guangdong Provincial Plan for Constructing Cultural Province (2011-2020). Article 10 of "Opinions on Implementation" is "to strengthen the protection and development of cultural heritage". It puts forward the proposal of "strengthening the protection and inheritance of the intangible cultural heritage, intensifying the protection of folk traditional arts represented by the "Tealeaf Picking Opera" in the north of Guangdong province and making the declaration, registration and transformation of cultural heritage well done. And "Opinions on Implementation" shows the positioning of local music in northern Guangdong and investment. It reflects that the municipal government pays much attention to local music in northern Guangdong. And the cultural departments and music workers would take the mission to dig, organize, explore and protect the traditional art. Japanese scholar Osamu Yamaguchi said that the cultural policies of the country should go beyond the simple legislation and management of those so-called "living national treasures" and "academic courses that respect traditional culture". In other words, the government should take a keen eye and insight to formulate viable protection strategy. Also, they should put it into practice. And they must provide protection measure to ensure the propagation of this cultural project (Yang Heping, 2012).

It is imperative to have the research on the theory and practice of the protection of intangible cultural heritage of music in northern Guangdong province. A slight hesitation and pause will lead to the invisible disappearance of musical culture. In addition to the several musical intangible cultural heritages that have been successfully listed in the provincial and national "List of Representatives of Intangible Heritage", there are still many undiscovered musical intangible cultural heritages carrying the unique spiritual values, modes of thinking and cultural awareness. We should take the protection and research. Also, we must inherit and carry forward these cultures. 


\section{The Functional Path to Combine Music COLLECTION COURSES WITH PROTECTION OF INTANGIBLE CULTURAL HERITAGE AND ITS EFFECTIVENESS}

The teaching reform of music collection has multiple functions. It would optimize professional teaching content, improve teaching quality, and enhance the ability to serve the local culture, stimulate students' enthusiasm and train the teachers.

The course team first carefully studied and analyzed the school-running orientation and training objectives. They studied personnel training programs and the teaching content of music teaching program. The course team explored the teaching methods, key teaching points and teaching modes. As music specialty of local undergraduate university, they analyzed the main purpose of the teaching of music collection course, the expected goal of the course, and the position and role of this course in the overall structure of personnel training. And then, they want to obtain clear and objective orientation, goal and requirements. Then, the teachers would have the corresponding accumulation of knowledge to guide the students. The whole process is well organized. In the early stage, we should have scientific planning. Also, we should make good preparation for it.

Before taking the music collection, the teachers set up a series of pre-prepared courses of professional knowledge such as "Folk Music", "Appreciation of Local Music in North Guangdong", "Appreciation of Folk Songs", "Appreciation of Drama", "Folk Dance", "Recording technology" and professional lectures on field study methods. Also, the teachers set up some courses of art practice. It includes "professional trainee", "professional music collection" and "art practice". It generally takes one or two weeks. Through these courses and seminars, students will be encouraged to deepen their understanding of ethnic folk music, folk dance, and related customs, ritual activities, folk beliefs, history and culture, language features, fieldwork and collection procedures and methods in northern Guangdong. They would have a solid foundation for the practice of art collection, establish correct professional ethics, rigorous academic awareness, master the standards of data collection, and make good preparations for theory and technology. The music collecting course focuses on enhancing the students' artistic skills, strengthening the practice of arts, expanding the employment opportunities, and arousing students' enthusiasm and sense of participation.

By combining music collection with intangible cultural heritages, it would increase the academic, authenticity, pertinence and objectivity of music collection. Also, it would cultivate, guide, exercise and enhance students' interest and ability in the study of folk music in northern Guangdong. Through field collection, interviews, multi-modal recording, artistic practice and the exhibition of artistic achievements, such as the concluding report, papers, research reports, recordings, videos, photographs, etc., the students would have a sense of satisfaction, the sense of value and the sense of accomplishment. It enables some students to realize their dream of publishing scientific research in major projects during their undergraduate studies. And it would enhance their innovative and entrepreneurial abilities. With this display and exchange, many students can learn independently. They would have independent innovation. It would form virtuous circle. At the same time, it can improve the spirit of collaboration among students. Music collection also has the function of strengthening the construction of teachers. With thematic lectures and guidance activities of music collection, the research abilities of middle-aged and young music teachers in the music college have been further enhanced in teaching quality.

Based on the support from the colleges and the relevant project funds of the Propaganda Department of this Municipality, the course group collects the music cultural materials in northern Guangdong. It plans to build the exhibition room of local music, multimedia studio and multimedia information repository in northern Guangdong within two years. It would include local music books, precious original music data, music scores, folk instruments, $\mathrm{CD}, \mathrm{VCD}, \mathrm{LD}$ and other various audio and video materials. And then, it would realize the cultural resources sharing among the university, the government and the public.

It combines the music collecting course with teachers' research projects and students' creative projects. The teachers organize students to write research reports on the music collection. The center curriculum group forms a special research report based on the research materials collected by masters and students. It would provide suggestion for the formulation of the policy and the exaction, inheritance, protection, development of intangible cultural heritage. It would provide real support for the development of music in northern Guangdong, the excavation, sorting, protection of intangible cultural heritage and cultural exchanges.

The course team has formulated meticulous plans for the activities of intangible cultural heritage and rigorous data collection. The teachers should guide the practice of collecting folk songs in all directions. They also should ensure the safety of the activity. Also, they must ensure the successful completion of established teaching objectives in field trips and music collection activities. The course group arranged and presented many historical documents and materials on local music culture in northern Guangdong. It clearly defined the generation, development and inheritance of local music and focused on the investigation and study of the current situation of local music and cultural ecology in northern Guangdong. It has studied the current living conditions of regional music. They have tracked the folk entertainers and societies. And they have made the recording of the intangible cultural heritage in the northern Guangdong. The category of music intangible cultural heritage in northern Guangdong was divided into subdivisions of townships and villages under counties and cities. We should rescue the important music resources of counties and cities in sequence. As for their activities, inheritance, etc., we should conduct comprehensive survey, a series of in-depth interviews on local music performances.

The course team made statistics on the basic conditions of the heirs. It includes name, the number of artists, living conditions, economic conditions and the status of inheritor. 
Then, they would made distribution diagram. A number of teachers and students were assigned to go to the eight counties in three districts of northern Guangdong in phases. They would conduct intensive field investigation and interviews of folk music, opera and art groups, music organizations and folk artists in northern Guangdong. They identified its specific distribution and popular areas of provincial and national intangible cultural heritage. They also would sort and mark its general historical changes and living conditions. During the process of collecting the folk songs, the center conducted various attempts on data collection standards, especially sound recordings. According to the records of Dodecachordon, the center organizes the teachers and students to make the recognition. For the Dodecachordon with the national style, in order to preserve the authenticity, they should try to adopt the collection methods such as recording, video recording and photograph as much as possible to prevent distorting the original appearance and charm. They must obey the principles of the protection of intangible cultural heritage such as science, objectivity, authenticity. (Yu Jie, 2008).

The center and course group conducted in-depth and systematic pre-collation studies by making in-depth use of the materials of the college library and the various departments of New Bureau in Guangguang, as well as the field surveys and related research results of the local music accumulated by the college over the years. The center would organize teachers and students to compile, organize, present and study local music and culture in northern Guangdong in phases. It includes photos, audio and video. They should record CDs, purchase relevant documents and extensively collect books, audiovisuals and videos, periodicals and other information from local institutions and individuals in counties and cities. The center and the curriculum group adopted the teaching method of "introduction". Under the support of the college, they hired cultural organizers from cities and counties, social artists of various art forms and social teachers. It would bring folk music into music hall, exhibition hall, college hall and piano room in northern Guangdong. As the inheritor of intangible cultural heritage recognized by provincial and municipal cultural departments, the folk artists are authoritative in their devotion and perseverance as well as superb skills. They can inspire students to respect their history and love local culture. Therefore, the students would respect and love local culture. The center has reached cooperation with the inheritors of local intangible cultural heritage. They can donate all their manuscripts and materials to the showroom of the achievements. They would be the treasures in the future.

The center organizes teachers and students to make detailed and in-depth collection of local music in northern Guangdong based on the music collecting course. The teachers and students should arrange and study local music in time. The teachers should apply the research results to the teaching. It would achieve outstanding results. The teachers of center and academy organize the practice of art collection. These projects include Tea-picking Opera in northern Guangdong, Flower Drum Opera in Lechang, Plum in Qujiang, Folk Songs in Ruyuan, Yuejie song in Renhua,
Dragon Boat Tune in Nanxiong, Jiufeng folk songs in Wengyuan, Hakka folk songs, Panwang songs, long drum dance of Yao nationality, hanging ceremony in Yuyuan and other researches. It collected a large number of text information and first-hand music elements. The course team tried to extract local music elements in northern Guangdong and created original works with the characteristics of music and culture in northern Guangdong. And it reflects that the local colleges and universities serve local culture. In the past two years, the center and the music collection courses published "Tea-picking Drama in northern Guangdong" and "Studies on music in Shaoguan". It obtains 5 provincial teaching and research projects and 6 municipal teaching and research projects. In terms of educating people, the course team guides students to complete 4 provincial and national undergraduates' innovative projects. Also, it guides 70 students' graduation thesis designs. Under the guidance of their tutors, more and more students start the papers of local music and culture. These students are familiar with the collection process. And it improves their writing ability. The teachers of curriculum team published more than 20 articles on related teaching and studies. In the music creation, the teachers of the course group created "She Sheng Ya" based on the elements of music in northern Guangdong. It got the third prize of the second college students' instrumental music competition in Guangdong province. They successfully held the dance studio of "the first sight of Guangdong province".

\section{CONCLUSION}

The cultivation of innovative talents is a systematic project. Today, we should focus on the quality of education, highlight the status and function of college students' art practice activities, summarize the relationship between art practice activities and the cultivation of innovative talents, and guide young students to actively engage in artistic practice activities. The music talents must meet the requirements of the times. It undoubtedly has a very important significance. The most important feature of the organic combination of music collection and intangible cultural heritage protection is to highlight the local cultural services for local colleges and universities. Based on the local needs, they serve northern Guangdong province. The local music and dance center in Northern Guangdong province and music collection group will connect personnel training with service for local music culture. The colleges and universities should link theoretical teaching with the practice of folk music collection, update co-education and teaching philosophy and training mode, and carry out indepth and systematic artistic teaching. One of the highlights of this exploration and practice is to highlight students' artistic practice and creativity. The center and the curriculum team make full use of the art practice curriculum and core professional skills curricula in the cultivation program of talents. The college should carry out systematic and in-depth teaching collection, excavate the precious original materials of local music in northern Guangdong province, explore the origins, distribution, inheritance and characteristics of local music in northern Guangdong province, form a series of essays and monographs, improve the popularity of local music in northern Guangdong province, promote the 
construction of music collecting course and the construction of musicology discipline. The reform achieved remarkable results. In addition to the achievements, we are also thinking about some deep-seated problems in the process of combining music collection and intangible cultural heritage protection. For example, the music collecting course is only an art practice course, and it is related to students' professional and graduate internships. Some of the content is repeated. These colleges and universities should make a more reasonable convergence, allocate the financing problem of the professional and artistic practice, solve the problem of low pay for external lecturers, and protect the sustainable development of folk songs after local census. These problems need to be resolved in time.

\section{REFERENCES}

[1] Xiang Yunju. Oral intangible cultural heritage [M]. Yinchuan: Ningxia People's Education Press, 2013: 315.

[2] Editorial Board of Word-ocean Dictionary. Word-ocean dictionary [Z]. Shanghai: Shanghai Dictionary Press, 1989: 1683.

[3] Etymology Editorial Board. Etymology [Z]. Beijing: Commercial Press, 1998: 1710 .

[4] Yang Heping. The double vision of fieldwork and intangible cultural heritage preservation [J]. Explorations In Music, 2012 (3): 42-47.

[5] Yu Jie. Analysis and suggestions on the reform of "Collecting music" in music specialty of local colleges and universities [J]. Journal of Jiangxi Normal University, 2008 (6): 137-139.

[6] Zhang Xinxin, Wen Zhen. Exploration on inheritance pathways of intangible cultural heritage protection and college education [J]. Southern Forum, 2015 (8): 69-71. 